Original Research Article

\title{
Randomized clinical study comparing safety and efficacy of adjuvant intrathecal clonidine versus normal saline along with bupivacaine anaesthesia in lower limb surgery patients
}

\author{
Brijesh Kumar ${ }^{1}$, Kiran Shetty ${ }^{2}$, Vijaya Kiran Shetty ${ }^{3}$, Suresha K. R. ${ }^{4 *}$
}

\begin{abstract}
${ }^{1}$ Department of Anaesthesia and Critical Care, Akash Institute of Medical Sciences \& Research Centre, Devanahalli, Bangalore 562110, Karnataka, India ${ }^{2}$ Department of Anaesthisiology and Critical Care, Sparsha Hospital, Bangalore, Karnataka, India

${ }^{3}$ Department of Anaesthisiology, Bangalore Medical College, Bangalore, Karnataka, India ${ }^{4}$ Department of Pharmacology, Akash Institute of Medical Sciences \& Research Centre, Devanahalli, Bangalore 562110, Karnataka, India
\end{abstract}

Received: 28 October 2017 Accepted: 03 November 2017

*Correspondence to: Dr. Suresha K. R., Email: drsuresh_pharmac@ rediffmail.com

Copyright: (c) the author(s), publisher and licensee Medip Academy. This is an openaccess article distributed under the terms of the Creative Commons Attribution NonCommercial License, which permits unrestricted noncommercial use, distribution, and reproduction in any medium, provided the original work is properly cited.

\begin{abstract}
Background: Various adjuvants have been used in intrathecal anesthesia to avoid intraoperative visceral and somatic pain and prolong postoperative analgesia. Clonidine, partially selective $\alpha 2$-agonist, is being evaluated as a neuraxial adjuvant with intrathecal bupivacaine. The objective of the study was to evaluate and compare safety and efficacy of intrathecal clonidine as adjuvant to bupivacaine with control normal saline.
\end{abstract}

Methods: American Society of Anesthesiologist grade 1 and 2 patients (60 patients) were randomly divided into two groups of 30 patients each for lower limb surgeries. Study group injected with intrathecal $3 \mathrm{ml}$ of $0.5 \%$ Bupivacaine heavy $(15 \mathrm{mg})+1 \mu \mathrm{g} / \mathrm{kg}$ of clonidine and control group injected with $3 \mathrm{ml}$ of $0.5 \%$ Bupivacaine heavy $(15 \mathrm{mg})+$ equivalent dose of normal saline. The onset and duration of sensory and motor block, duration of analgesia, and the incidence of side effects in both groups were observed and compared.

Results: Time for 2 segment regressions in study group was $186.17 \pm 25.92$ minutes compared to control was $103.20 \pm 19.15$ minutes (p value $<0.001$ ). Total duration of analgesia in control was $226.50 \pm 35.69$ minutes and in the study group was $465.67 \pm 100.37$ minutes ( $\mathrm{p}$ value $<0.001$ ). The average duration of motor block in control group was $181.17 \pm 26.12$ minutes compared to study group was $217.80 \pm 41.51$ minutes ( $p$ value $<0.001$ ). The small dose of intrathecal clonidine is not significantly associated with systemic side effects such as bradycardia and hypotension.

Conclusions: Clonidine added to bupivacaine for intrathecal anesthesia effectively increases the duration of sensory block, duration of motor block and duration of analgesia and does not produce any significant hemodynamic changes. No significant side effects are associated with it.

Keywords: Bupivacaine, Clonidine, Intrathecal anesthesia, Lower limb surgeries

\section{INTRODUCTION}

Intrathecal anaesthesia commonly includes spinal and epidural anaesthesia. Spinal anaesthesia is defined as the temporary interruption of transmission of the nerve fibers 
by injecting drug into the sub arachnoid space. It is safe and satisfactory if performed with the knowledge of its physiologicalconsequences and in many instances, it is the method of choice in view of patient's condition and produces an ideal operating condition and post operative pain relief. ${ }^{1}$

Local anaesthetics are used widely for the provision of anaesthesia and analgesia both intra- and post-operatively. They are used as the sole form of anesthesia, or in combination with general anesthesia. Development of local anesthetics, since the 1950s, has focused on amide local anesthetics (Lignocaine, Prilocaine, Bupivacaine) rather than ester local anesthetics because of number of limitations including instability in solution form, short shelf life, degradation when exposed to high temperatures, and an increased propensity to cause allergic reactions. The potency, duration, and onset of action for a local anesthetic are dependent upon lipophilic-hydrophobic balance and hydrogen ion concentration. ${ }^{2}$

For decades lignocaine has been the neuroaxial anesthetic of choice. Though it has many advantages in the form of rapid onset of action, good motorblock manifested as good muscle relaxation. Nowadays its use is limited by increased incidences of neurological symptoms or transient radicular irritation. ${ }^{3}$ But bupivacaine is more potent than lignocaine and has longer duration of action. Its disadvantages are slow onset of action and decreased motor block. ${ }^{4}$ Hyperbaric bupivacaine $0.5 \%$ is extensively used local anaesthetic via intrathecal route. Though the duration of action of bupivacaine is prolonged, it will not produce prolonged post operative analgesia. So there is need for adjuvant for producing prolonged post operative analgesia. Several adjuvants have been used to prolong the duration of spinal anaesthesia. Vasoconstrictors like phenylephrine, opioids, dextran-40; carbonated local anaesthetics, proteins, potassium etc are some of well known agents. Morphine was the first and most commonly used opioid adjuvant for intrathecal administration with local anaesthetics producing intense, prolonged and segmental analgesic action without gross autonomic changes, loss of motor power or impairment of sensation other than pain when injected into subarachnoid or epidural space. However side effects such as potentially catastrophic, delayed res piratory depression, postoperative nausea and vomiting, pruritus, urinary retention etc have prompted further research to develop non- opioid analgesics with less worrisome side effects. ${ }^{5}$

Clonidine is of interest because it preserves cardiovascular reflexes, provides sedation, provides greater intra operative hemodynamic stability and a reduction in anaesthetic and postoperative analgesics requirements and also has a marked opioid sparing effect, further more intrathecal clonidine prolongs the duration of hyperbaric bupivacaine spinal block. ${ }^{6,7}$ Hence the present study was undertaken to evaluate the safety and efficacy of low dose intrathecal clonidine $(1 \mu \mathrm{g} / \mathrm{kg})$ as an adjuvant to hyperbaric bupivacaine for lower limb surgeries and compare with normal saline as control adjuvant.

\section{METHODS}

\section{Study design}

Randomized double-blinded clinical study, in which patients either injected with $3 \mathrm{ml}$ of $0.5 \%$ Bupivacaine heavy $(15 \mathrm{mg})+1 \mu \mathrm{g} / \mathrm{kg}$ of clonidine hydrochloride (Study Group) or injected with $3 \mathrm{ml}$ of $0.5 \%$ Bupivacaine heavy $(15 \mathrm{mg})+$ equivalent dose of normal saline (Control group). The simple randomization technique was used. This was double blinded using opaque sealed envelope; both patients and the anesthesiologists/nurses managing patients were blinded to knowledge of the group to which they belonged.

\section{Study participants and eligibility criteria}

This study was initiated after hospital research and ethics committee approval and written informed consent from the participants. 60 adult patients belonging to ASA Grade I and II aged between 20 and 50 years scheduled for various elective lower limb surgeries under spinal anaesthesia were included. A thorough preanaesthetic evaluation (PAE) was conducted on the day before surgery. PAE included history, clinical examination, and systemic examination was done. Investigations such as hemoglobin, total counts, differential count, erythrocyte sedimentation rate, urine routine, random blood sugar, electrocardiogram (ECG), chest X-ray, serum aminotranferases, bilirubin, serum creatinine, and blood urea were done before PAE. Patients with history of hypertension, ischemic heart disease, cerebrovascular accidents and endocrinal diseases like diabetes and pheochromocytoma and patients on chronic administration of $\alpha 2$ agonist medication for hypertension were excluded from the study. Patients were pre-medicated with oral diazepam $0.1-0.2 \mathrm{mg} / \mathrm{kg}$ and oral pantoprazole $40 \mathrm{mg}$ night before the surgery and were fasted for 8 hours preoperatively.

\section{Interventions}

In the operation theatre, an IV access was secured and started with Dextrose Normal Saline. Patients were connected to monitor that shows non invasive blood pressure (BP), ECG, heart rate (HR) and arterial oxygen saturation. Basal heart rate, systolic and diastolic BP, respiratory rate (RR) and arterial oxygen saturation were noted. Patients were preloaded with $15 \mathrm{ml} / \mathrm{kg}$ RL over 15 minutes before subarachnoid block. Patients were placed in left lateral decubitus position for lumbar puncture. Under strict aseptic precautions a lumbar puncture was performed through a midline approach using either a $25 \mathrm{G}$ or $27 \mathrm{G}$ spinal needle at L3-L4 intervertebral space. Once a free flow of cerebrospinal fluid was obtained, the following test drugs were given to the patients as per the randomization list. 
- Study Group - injected with $3 \mathrm{ml}$ of $0.5 \%$ Bupivacaine heavy $(15 \mathrm{mg})+1 \mu \mathrm{g} / \mathrm{kg}$ of clonidine hydrochloride. ${ }^{8}$

- Control group - injected with $3 \mathrm{ml}$ of $0.5 \%$ Bupivacaine heavy (15mg) + equivalent dose of normal saline.

After the injection the patient was returned to supine position and was retained in that position for 20 minutes before positioning for surgery.

\section{Outcomes}

The following parameters were recorded in all patients. Extent of sensory blockade- the highest level of sensory blockade was checked by pinprick sensation. Degree of motor blockade is checked according to Bromage scale.? Duration of anaesthesia, duration of surgery, HR, NIBP (SBP, DBP), ECG, $\mathrm{SPO}_{2}$ and $\mathrm{RR}$ are monitored at every 5 minutes for first half an hour and then at 15 minutes intervals. Adverse effects are monitored. Sedation scoring was done (0- No sedation; 1- Drowsiness; 2- Asleep but arousable; 3- Unarousable with loss of verbal contact)

\section{Statistical analysis}

Descriptive and inferential statistical analysis was used in our study. Results on continuous measurements were presented on Mean \pm standard deviation and results on categorical presented in Number (\%). Student t test (two tailed, dependent) was used to find the significance of study parameters on continuous scale within each group. Chi square/ Fisher Exact test was used to find the significance of study parameters on categorical scale between two or more groups. Significance was assessed at $5 \%$ level of significance $(\mathrm{P})$.

\section{RESULTS}

Table 1: Baseline demographic profile of the patients.

\begin{tabular}{|llll|}
\hline Parameters & $\begin{array}{l}\text { Control group } \\
\text { (Bupivacaine } \\
\text { +Normal } \\
\text { saline) } \\
\text { (Mean } \pm \text { SD) }\end{array}$ & $\begin{array}{l}\text { Study group } \\
\text { (Bupivacaine } \\
\text { + Clonidine) } \\
\text { (Mean } \pm \text { SD) }\end{array}$ & $\begin{array}{l}\text { p } \\
\text { Value }\end{array}$ \\
\hline Age (Yrs) & $38.37 \pm 9.09$ & $37.77 \pm 9.77$ & 0.806 \\
\hline Weight (kgs) & $61.40 \pm 9.80$ & $61.50 \pm 9.59$ & 0.968 \\
\hline Sex (M:F) & $21: 9$ & $22: 8$ & 0.774 \\
\hline $\begin{array}{l}\text { ASA I / ASA } \\
\text { II }\end{array}$ & $22 / 8$ & $21 / 9$ & 0.774 \\
\hline Heart Rate & $87.23 \pm 10.58$ & $85.97 \pm 8.29$ & 0.608 \\
\hline Systolic BP & $130.97 \pm 9.80$ & $130.40 \pm 11.38$ & 0.835 \\
\hline Diastolic BP & $84.47 \pm 4.49$ & $84.13 \pm 8.08$ & 0.844 \\
\hline $\begin{array}{l}\text { Respiratory } \\
\text { rate }\end{array}$ & $16.07 \pm 0.87$ & $16.03 \pm 0.96$ & 0.889 \\
\hline SPO 2 & $99.63 \pm 0.49$ & $99.53 \pm 0.78$ & 0.964 \\
\hline $\begin{array}{l}\text { Sedation } \\
\text { score (1-5) }\end{array}$ & $1($ awake) & $1($ awake) & \\
\hline
\end{tabular}

A total number of 71 patients were screened for the eligibility and 60 were enrolled. Excluded 11 patients (hemodynamic instability $=03$, prior clonidine usage $=02$, contraindications to study drugs $=05$, refused consent $=01$ ) and 60 patients were randomized into the two groups (Study and control group). Baseline demographic profile of the patients is shown in Table 1.

Both the groups are comparable with respect to age, gender distribution, hemodynamic parameters, and sedation scores etc. The distribution of various surgical procedural indication among the both the groups is depicted in Table 2.

Table 2: Distribution of surgical procedures among both the groups.

\begin{tabular}{|lllll|}
\hline Surgery & $\begin{array}{l}\text { Control } \\
(\mathbf{n = 3 0})\end{array}$ & group & \multicolumn{2}{l|}{$\begin{array}{l}\text { Study } \\
(\mathbf{n = 3 0})\end{array}$} \\
& No & $\mathbf{\%}$ & $\mathbf{N o}$ & $\mathbf{\%}$ \\
\hline ACL repair & 2 & 6.7 & 3 & 10.0 \\
\hline Arthroscopy & 3 & 10.0 & 1 & 3.3 \\
\hline Bone grafting & 0 & 0.0 & 1 & 3.3 \\
\hline Exchange nailing & 0 & 0.0 & 2 & 6.7 \\
\hline Fis surectomy & 1 & 3.3 & 0 & 0.0 \\
\hline Fistulectomy & 1 & 3.3 & 0 & 0.0 \\
\hline Flap covering & 1 & 3.3 & 0 & 0.0 \\
\hline Haemorroidectomy & 2 & 6.7 & 1 & 3.3 \\
\hline Hernia repair & 3 & 10.0 & 5 & 16.7 \\
\hline Hydrocelectomy & 2 & 6.7 & 1 & 3.3 \\
\hline IL Nailing & 1 & 3.3 & 2 & 6.7 \\
\hline IM nailing & 2 & 6.7 & 0 & 0.0 \\
\hline Implant removal & 0 & 0.0 & 2 & 6.7 \\
\hline ORIF & 4 & 13.3 & 4 & 13.3 \\
\hline PFN & 1 & 3.3 & 0 & 0.0 \\
\hline Sequestrectomy & 1 & 3.3 & 0 & 0.0 \\
\hline Skin grafting & 0 & 0.0 & 2 & 6.7 \\
\hline Stripping & 0 & 0.0 & 2 & 6.7 \\
\hline TBW & 2 & 6.7 & 1 & 3.3 \\
\hline Varicocelectomy & 1 & 3.3 & 0 & 0.0 \\
\hline Others & 3 & 10.0 & 3 & 10.0 \\
\hline
\end{tabular}

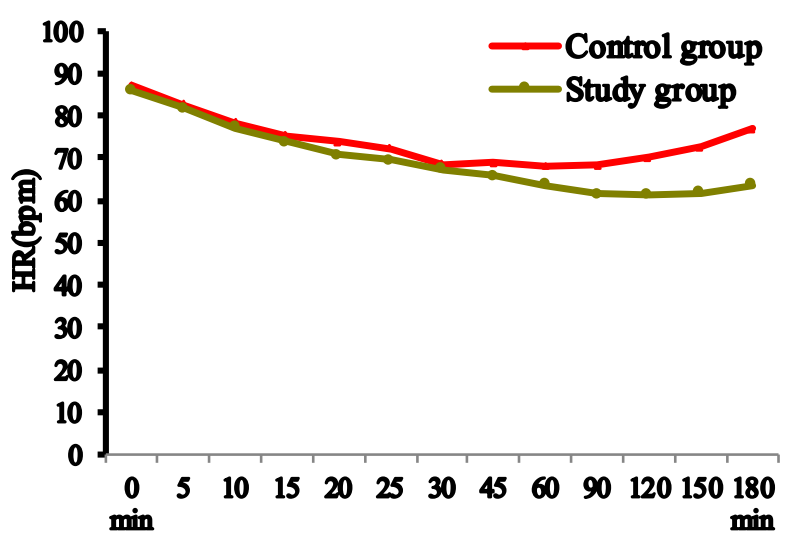

Figure 1: Comparis on of mean heart rate at various time intervals. 
The comparis on of the mean heart rates between the groups is shown in Figure 1. The decrease in mean heart rate from 45 minutes until the end of 3 hours was greater in Clonidine group than in the Control group $(\mathrm{P}<0.001)$. In addition, the decrease from baseline value within the Clonidine group was also statistically significant at 45 minutes to the end of 3 hours. Only 2 patients in control group had bradycardia whereas 4 patients had bradycardia in clonidine group.

The comparis on of mean systolic blood pressure at various time intervals is shown in Figure 2. The decrease in mean SBP after 120 minutes until the end of 3 hours was greater in clonidine group than in the control group $(\mathrm{P}<0.001)$.

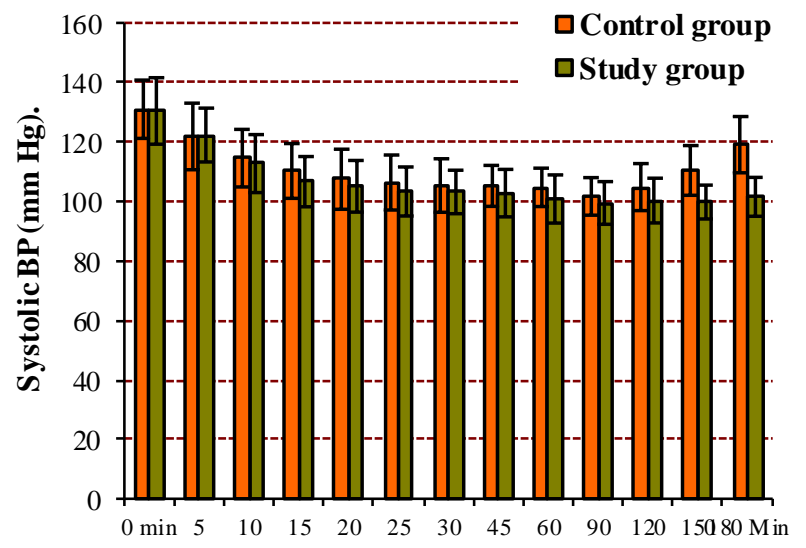

Figure 2: Comparison of mean systolic blood pressure at various time intervals.

The Comparison of mean DBP at various time intervals is shown in Figure 3. The decrease in mean diastolic blood pressure from 30 minutes until the end of 3 hours was greater in clonidine group than in the control group $(\mathrm{P}<0.001)$.

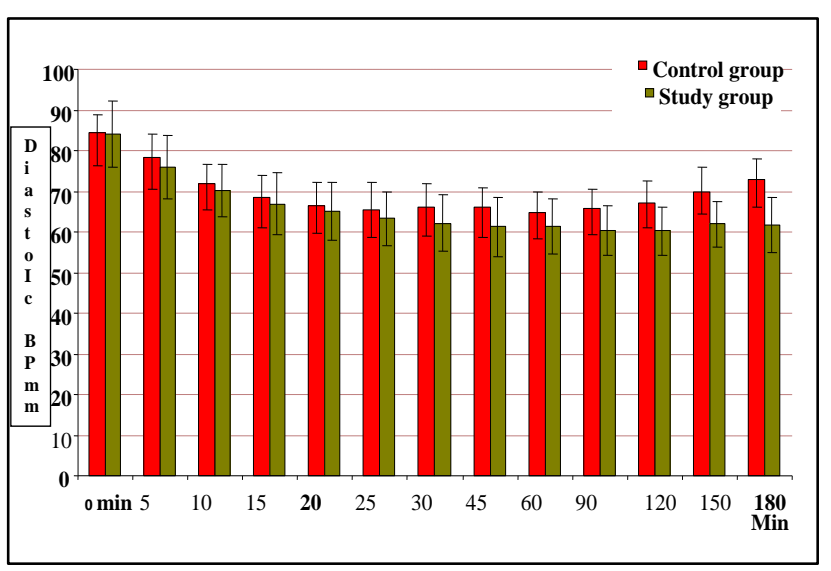

Figure 3: Comparison of mean diastolic blood pressure at various time intervals.

In addition, the decrease from baseline value within the study group was also statistically significant at 45 minutes to the end of 3 hours. 7 patients had hypotension in control group whereas 9 patients had hypotension in study group.
The comparis on of mean $\mathrm{SpO}_{2}$ at various time intervals shown in Figure 4.

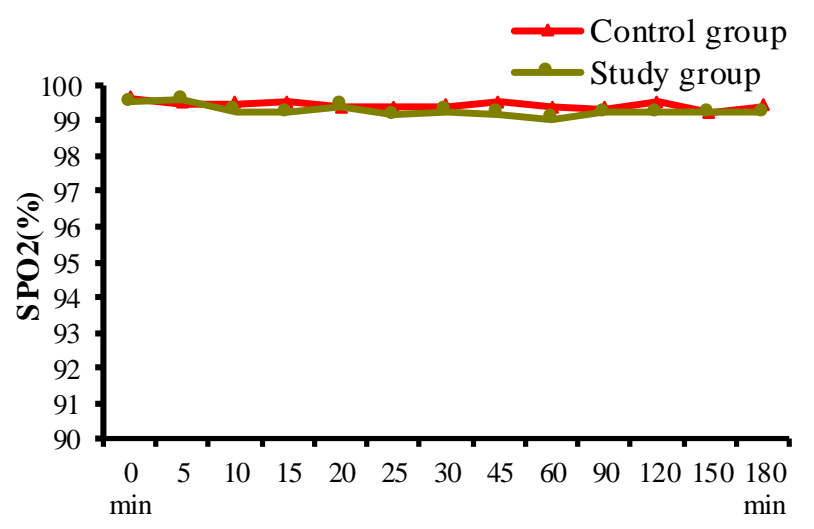

Figure 4: Comparison of mean $\mathrm{SpO}_{2}$ at various time intervals.

There was no significant change in $\mathrm{SpO} 2$ from the baseline in both the groups $(\mathrm{P}>0.05)$. The comparis on of study parameters (duration of surgery, regression of sensory analgesia by two segments, duration of motor blockade and time for rescue analgesia) between two groups is shown Table 3.

Table 3: Comparison of study parameters between two groups.

\begin{tabular}{|llll|}
\hline $\begin{array}{l}\text { Study } \\
\text { parameters }\end{array}$ & $\begin{array}{l}\text { Control } \\
\text { group }(\mathbf{n}=\mathbf{3 0})\end{array}$ & $\begin{array}{l}\text { Study group } \\
(\mathbf{n}=\mathbf{3 0})\end{array}$ & P value \\
\hline $\begin{array}{l}\text { Duration of } \\
\text { Surgery }\end{array}$ & $117.83 \pm 29.23$ & $121.67 \pm 34.85$ & $\begin{array}{l}\mathrm{t}=0.462 ; \\
\mathrm{p}=0.646\end{array}$ \\
\hline $\begin{array}{l}\text { Time for } 2 \\
\text { segment } \\
\text { regressions } \\
\text { of sensory } \\
\text { block }\end{array}$ & $103.20 \pm 19.15$ & $186.17 \pm 25.92$ & $\mathrm{t}=14.007 ;$ \\
\hline $\begin{array}{l}\text { Duration of } \\
\text { motor } \\
\text { blockade }\end{array}$ & $181.17 \pm 26.12$ & $217.80 \pm 41.51$ & $\mathrm{t}=4.091 ;$ \\
\hline $\begin{array}{l}\text { Time for } \\
\text { first rescue } \\
\text { analgesia }\end{array}$ & $226.50 \pm 35.69$ & $465.67 \pm 100.37$ & $\mathrm{t}=12.297 ;$ \\
\hline
\end{tabular}

There was no statistically significant difference in the duration of surgery between both the groups $(\mathrm{P}>0.05)$. The time taken for regression of sensory analgesia by two segments was significantly more in study group (186.17 $\pm 25.92 \mathrm{~min})$ when compared to control group $(103.20 \pm 19.15 \mathrm{~min}) \quad(\mathrm{P}$ value $<0.001)$. The duration of motor blockade was significantly longer in study group $(217.80 \pm 41.51 \mathrm{~min})$ when compared to control group (181.17 $\pm 26.12 \mathrm{~min}) \quad$ (P value <0.001). The time for first rescue analgesia in clonidine group was significantly more $(465.67 \pm 100.37 \mathrm{~min})$ when compared to control group $(226.50 \pm 35.69 \mathrm{~min})$ (P value $<0.001)$. Comparison of extent of sensory blockade achieved in both the groups is 
depicted in Figure 5. The Comparis on of Sedation score is shown in Table 4.

Table 4: Comparis on of Sedation score.

\begin{tabular}{|lll|}
\hline $\begin{array}{l}\text { Sedation } \\
\text { score }\end{array}$ & $\begin{array}{l}\text { Control group } \\
(\mathbf{n = 3 0})\end{array}$ & $\begin{array}{l}\text { Study group } \\
(\mathbf{n}=\mathbf{3 0})\end{array}$ \\
\hline 0 & $26(86.7 \%)$ & $5(16.7 \%)$ \\
\hline 1 & $4(13.3 \%)$ & $9(30.0 \%)$ \\
\hline 2 & 0 & $16(53.3 \%)$ \\
\hline Mean \pm SD & $0.13 \pm 0.35$ & $1.37 \pm 0.77$ \\
\hline Inference & $\begin{array}{l}\text { Study group had significantly higher } \\
\text { sedation score with } \mathrm{P}<0.001 * *\end{array}$ \\
\hline
\end{tabular}

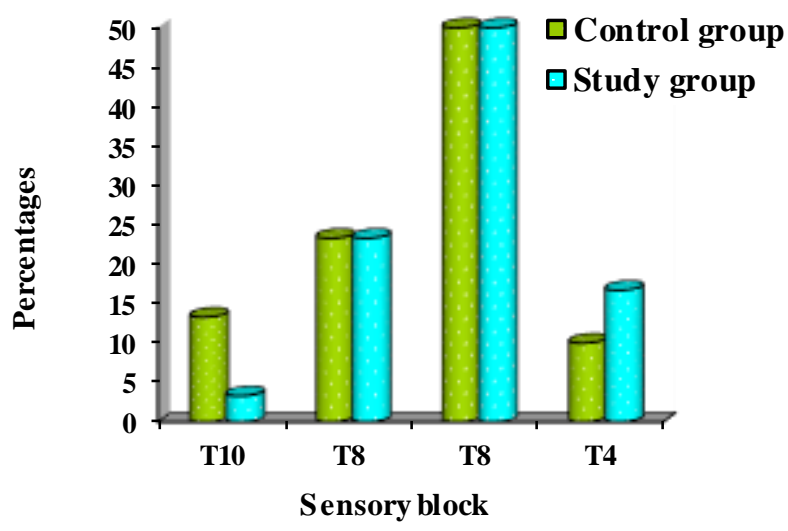

Figure 5: Comparison of extent of sensory blockade achieved in both the groups.

The incidence of sedation was significantly higher in clonidine group (1.37 $\square 0.77)$ compared to control group (0.13 $\square 0.35) \quad(\mathrm{P}<0.001)$. The Comparison of various adverse effects between both the groups is depicted in Figure 6. There was statistically no significant difference in the incidence of nausea, vomiting, dry mouth, desaturation, bradycardia and hypotension between both the groups whereas the incidence of shivering was significantly less in study group $(6.7 \%)$ than the control group $(26.7 \%) \quad(\mathrm{P}<0.05)$.

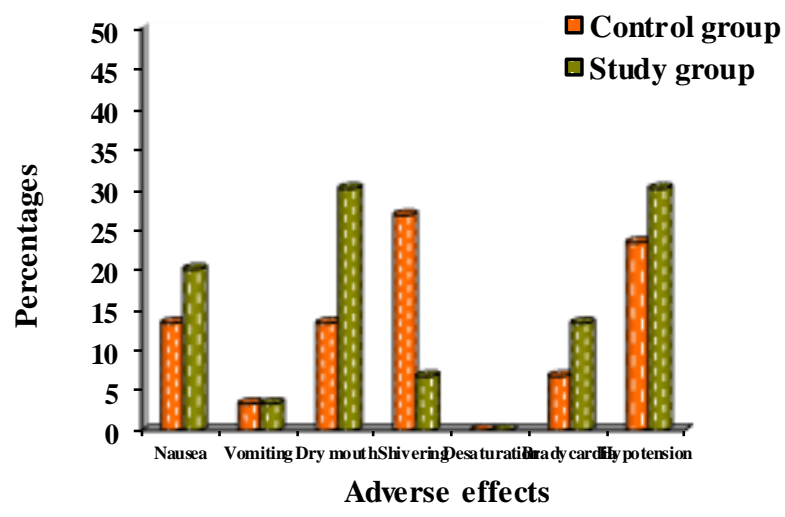

Figure 6: Comparison of various adverse effects between both the groups.

\section{DISCUSSION}

The spinal anesthesia is preferred for lower limb surgeries as it is simple, easy to perform, and economical with rapid onset of anesthesia and complete muscle relaxation. In our study, we used $0.5 \%$ hyperbaric bupivacaine to create subarachnoid block. ${ }^{10}$

In the present study, results showed that the addition of clonidine in the dose of $1 \mu \mathrm{g} / \mathrm{kg}$ to $0.5 \%$ bupivacaine increased the duration of sensory block, motor block and duration of analgesia in patients undergoing lower limb surgeries. Clonidine is a selective partial agonist for $\alpha 2$ receptor, moderately lipid soluble and easily penetrates the blood-brain barrier, leading to spinal and supraspinal receptor binding and thus provides effective and longlasting postoperative analgesia. They act by binding to presynaptic C-fibers and postsynaptic dorsal horn neurons. ${ }^{11}$

Their analgesic action is a result of depression of the release of C-fiber transmitters and hyperpolarization of postsynaptic dorsal horn neurons. The prolongation of effect may result from synergis $m$ between local anesthetics and $\alpha 2$-adrenergic agonists to motor neurons in the dorsal horn. ${ }^{12}$

\section{Sensory characteristics and analgesia}

Clonidine produces spinal cholinergic activation with cholinergic interaction in spinal $\alpha 2$ adrenoceptors and produces noradrenaline release in the descending noradrenergic pathways which causes analgesia. In addition it stimulates release of acetylcholine which enhances analgesia. ${ }^{13}$ The analgesic action of clonidine may be at peripheral, spinal and brainstem sites. It does produce a minor degree of nerve conduction blockade at very high concentration with some preference for $\mathrm{C}$ fibres. ${ }^{14}$ This conduction blockade may underlie, in part, the enhancement of peripheral nerve block when this agent is added to bupivacaine. Spinal action of clonidine through release of acetylcholine and noradrenaline has also been proposed as the mechanism of action of prolonging spinal. ${ }^{15}$

In our study it was noticed that the maximum level of sensory blockade achieved both the groups were similar at T6 segment. The time for 2 segmental regression of sensory blockade was compared, it was seen that the time for 2 segment regressions in study group was $186.17 \pm 25.92$ minutes and in control group it was $103.20 \pm 19.15$ minutes ( $\mathrm{p}$ value $<0.001$ ). The total duration of analgesia in control group was $226.50 \pm 35.69$ minutes and in the study group it was $465.67 \pm 100.37$ minutes ( $p$ value $<0.001$ ). This shows that clonidine prolongs the duration of postoperative analgesia. Our study is consistent with that of BS. Sethi et al, and Strebel, et al. ${ }^{16,17}$ 


\section{Motor characteristics}

Dobrydnjov et al, 76 noted that intrathecal clonidine alone even in doses of $450 \mu \mathrm{g}$ does not induce motor block or weakness. In contrast, intrathecal clonidine combined with local anaesthetics significantly potentiates the intensity and duration of motor blockade. The explanation for this could be that $\alpha 2$ agonist induce cellular modification in the ventral horn of spinal cord (motoneuron hyperpolarisation) and facilitate local anaesthetic action. ${ }^{18,19}$ Clonidine may cause local vasoconstriction, thereby reducing vascular removal of local anaesthetics surrounding the neural structures. This may also partly explain increased duration of motor blockade associated with clonidine administration. ${ }^{17}$

In present study the average duration of motor block in control group was $181.17 \pm 26.12$ minutes compared to study group $217.80 \pm 41.51$ minutes ( $\mathrm{p}$ value $<0.001$ ). Our results are consistent with BS Sethi et al. ${ }^{16,18}$

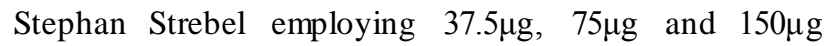
clonidine in addition to bupivacaine noted that complete motor blockade of lower extremities was observed in all the patients. After 4, 5, 6 and 7 hours the Bromage score was significantly higher in patients who received clonidine compared to control group.17The results of the present study concur with the studies of BS Sethi et al, Dobrydnjov et al, and Stephan Strebel et al.

\section{Sedation}

Sedation commonly accompanies the use of clonidine for regional anaesthesia, consistent with the known sedative/ anaesthetic sparing properties of $\alpha 2$ agonists by its action on locus coeruleus. ${ }^{20}$ This brainstem nucleus is associated with a wide variety of physiological regulatory responses, including regulation of sleep and wakefulness. This centre is inhibited by clonidine via a G-protein mediated mechanism that involves inhibition of adenyl cyclase. Several studies have demonstrated the reduced need for other sedatives and anxiolytic medications when clonidine is administered intraoperatively. ${ }^{21}$ In the present study number of patients with grade 2 sedation was 16 and number of patients with grade 1 sedation was 9 . All could be easily arousable and $\mathrm{SPO}_{2}$ was well maintained. Our results are in similar with BS Sethi et al, and Stephan Strebel. ${ }^{16,17}$

Hemodynamic changes: Clonidine affects BP in a complex fashion after neuraxial administration because of opposing actions at multiple sites. ${ }^{22}$

In nucleus tractus solitarius and locus coeruleus of brain stem, activation of postsynaptic $\alpha 2$ receptors reduces sympathetic drive. In addition, clonidine is not a pure $\alpha 2$ agonist. It also activates non adrenergic imidazoline preferring binding sites in the lateral reticular nucleus thereby producing hypotension and antiarrhythmogenic action. In the periphery activation of presynaptic $\alpha 2$ adrenoreceptors at sympathetic terminals reduces the release of epinephrine, which could cause vasorelaxation and reduced chronotropic drive. These brainstem and peripheral effects of $\alpha 2$ stimulation are counterbalanced by direct peripheral vasoconstriction from clonidine. As a result, the dose response for clonidine by neuraxial administration is $U$ shaped with peripheral vasoconstriction from circulating drug concentration at high doses opposing central sympatholys is. ${ }^{19}$

In addition, clonidine directly inhibits sympathetic preganglionic neurons in the spinal cord. The degree of clonidine induced hypotension is related to the spinal level of injection. Clonidine reduces heart rate, partly by a presynaptically mediated inhibition of nor adrenaline release at the neural receptor junction and partly by a vagomimetic effect. Hemodynamic effects begin within 30 minutes and reach maximum within 1-2 hours and lasts approximately 6-8 hours.

Dobrydnjov et al, 76 employing different doses of clonidine noted that mean arterial pressure was significantly lower during first 45-120 minutes in patients who received $15 \mu \mathrm{g}-30 \mu \mathrm{g}$ of clonidine. The maximal fall in mean arterial pressure was $11-19 \mathrm{mmHg}$ in patients who received $15 \mu \mathrm{g}$ of clonidine whereas the fall was 15$20 \mathrm{mmHg}$ in patients who received $30 \mu \mathrm{g}$ of clonidine. In control group the fall in mean arterial pressure was only 5$14 \mathrm{mmHg} .{ }^{18}$

In our study, we have observed small dose of intrathecal clonidine is not significantly as sociated with systemic side effects such as bradycardia and hypotension.

Benhamou et al, 84 also noted that hemodynanic changes in blood pressure and heart rate were not significant when bupivacaine in combination with clonidine was employed.

Chiari et al, noted that blood pressure and heart rate changes are seen usually with higher doses of clonidine $(>200 \mu \mathrm{g}) .^{23,24}$ In the present study only low dose clonidine $(1 \mu \mathrm{g} / \mathrm{kg})$ was employed and all the patients were preloaded with RL and hemodynamic changes were minimal in both the groups. The results of the present study concur with the results of Benhamou et al and Chiari et al.

\section{CONCLUSION}

The addition of clonidine $(1 \mu \mathrm{g} / \mathrm{kg})$ to bupivacaine for intrathecal anesthesia effectively increases the duration of sensory block, duration of motor block and duration of analgesia and does not produce any significant hemodynamic changes. No significant side effects are associated with addition of $1 \mu \mathrm{g} / \mathrm{kg}$ clonidine to $3 \mathrm{ml}$ of $0.5 \%$ Bupivacaine.

\author{
Funding: No funding sources \\ Conflict of interest: None declared \\ Ethical approval: The study was approved by the \\ Institutional Ethics Committee
}




\section{REFERENCES}

1. Mallikarjuna, Bindu, Davan KR, Mammen S, Sabreen S, Pooja P. Synergistic effects of intrathecal magnesium sulphate to the combination of bupivacaine and fentanyl spinal anaes thesia in patients undergoing lower abdominal surgeries Technology 2016;20(1):46-8.

2. Heavner JE. Pharmacology of local anesthetics. In D.E. Longnecker et al (eds) Anesthesiology. New York: McGraw-Hill Medical; 2008.

3. Zaric D, Leon N. Pace Transient neurologic symptoms (TNS) following spinal anaesthesia with lidocaine versus other local anaesthetics. Cochrane Database Syst Rev: 2009;(2):CD003006.

4. Balakrishnan K, Ebenezer V, Dakir A, Kumar S, Prakash D. Bupivacaine versus lignocaine as the choice of locall anesthetic agent for impacted third molar surgery a review. Journal of Pharmacy \& Bioallied Sciences. 2015;7(1):230-3.

5. Kaur M. Adjuvants to Local Anesthetics: Combination Wisdom. Anesthesia, Essays and Researches. 2010:122-123.

6. Mercier FJ, Dounas M, Bouaziz H, Des MesnardsSmaja V, Foiret C, Vestermann MN, et al. The effect of adding a minidose of clonidine to intrathecal sufentanil for labor analgesia. Anesthesiology: The Journal of the American Society of Anesthesiologists. 1998 Sep 1;89(3):594-601.

7. Missant C, Teunkens A, Vandermeersch E, Van de Velde M. Intrathecal clonidine prolongs labour analgesia but worsens fetal outcome: a pilot study. Can J Anaesth. 2004;51:696.

8. Rochette A, Raux O, Troncin R, Dadure C, Verdier R, Capdevila X. Clonidine prolongs spinal anesthesia in newborns: a prospective dose-ranging study. Anesthesia \& Analgesia. 2004 Jan 1;98(1):56-9.

9. Graham AC, McClure JH. Quantitative ass essment of motor block in labouring women receiving epidural analgesia. Anaesthesia. 2001 May 2;56(5):470-6.

10. Pederson H, Santos AC, Seinberg ES. Effects of varying doses of $0.5 \%$ hyperbaric bupivacaine on visceral pain during operations. Anaesthesiology. 1989;65:380-4.

11. Eisenach JC, De Kock M, Klimscha W. Alpha(2)adrenergic agonists for regional anesthesia. A clinical review of clonidine (1984-1995). Anaesthesiology 1996;85(3):655-74.

12. Harada Y, Nishioka K, Kitahata LM, Kishikawa K, Collins JG. Visceral antinociceptive effects of spinal clonidine combined with morphine, enkephalin, or U50, 488H. Anesthesiology. 1995;83:344-52.

13. Giovannitti Jr JA, Thoms SM, Crawford JJ. Alpha-2 adrenergic receptor agonists: a review of current clinical applications. Anesthesia progress. 2015 Mar;62(1):31-8.

14. Mandal SK, Biswas MR, Mondal SK, Das A, Das K. Intrathecal Clonidine Co-Administered with
Hyperbaric Bupivacaine in Infra-Umbilical SurgeryA Dose Response Study. Ann. Int. Med. Den. Res. 2016;2(6):27-32.

15. Eisenach J, Detweiler D, Hood D. Hemodynamic and analgesic actions of epidurally administered clonidine. Anaes thisiology. 1993:78;277-87.

16. Sethi BS, Samuel M, Sreevastava D. Efficacy of Analgesic Effects of Low Dose Intrathecal Clonidine as Adjuvant to Bupivacaine. Indian $\mathbf{J}$ of anaesthesia. 2007;51(5):415-9.

17. Strebel S, Gurzeler JA, Schneider MC, Aeschbach A, Kindler CH. Small-dose intrathecal clonidine and isobaric bupivacaine for orthopedic surgery: a doseresponse study. Anesthesia \& Analgesia. 2004 Oct 1;99(4):1231-8.

18. Dobrydnjov I, Axelsson K, Thorn SE, Matthiesen P, Klockhoff H, Olmstrom B, et al. Clonidine combined with small dose bupivacaine during spinal anesthesia for inguinal herniorrhaphy: A randomized doubleblinded study. Anesth Analg. 2003;96:1496-503.

19. Singh RB, Chopra N, Choubey S, Tripathi RK, Mishra A. Role of Clonidine as adjuvant to intrathecal bupivacaine in patients undergoing lower abdominal surgery: A randomized control study. Anesth Essays Res. 2014;8:307-12.

20. Eisenach JC, De Kock M, Klimscha W. $\alpha 2$-Adrenergic Agonists for Regional Anesthesia. A Clinical Review of Clonidine (1984-1995). The $\mathbf{J}$ of the American Society of Ane. 1996 Sep 1;85(3):655-74.

21. Gecaj-Gashi A, Terziqi H, Pervorfi T, Kryeziu A. Intrathecal clonidine added to small-dose bupivacaine prolongs postoperative analgesia in patients undergoing transurethral surgery. Canadian Urological Association Journal. 2012 Feb;6(1):25.

22. Jyothi VH, Safiya S. Prospective randomised study of combination of epidural bupivacaine with clonidine and bupivacaine for postoperative analgesia. Internet $\mathbf{J}$ Anaesth. 2012;30:2.

23. Benhamou D, Thorin D, Brichant JF, Dailland $P$, Milon D, Schneider M. Intrathecal clonidine and fentanyl with hyperbaric bupivacaine improves analgesia during cesarean section. Anesthesia \& Analgesia. 1998 Sep 1;87(3):609-13.

24. Chiari A, Lorber C, Eisenach JC, Wildling E, Krenn C, Zavrsky A, et al. Analgesic and Hemodynamic Effects of Intrathecal Clonidine as the Sole Analgesic Agent during First Stage of Labor A Dose-Response Study. Anesthesiology: The Journal of the American Society of Anesthesiologists. 1999 Aug 1;91(2):38896.

Cite this article as: Kumar B, Shetty K, Shetty VK, Suresha KR. Randomized clinical study comparing safety and efficacy of adjuvant intrathecal clonidine versus normal saline along with bupivacaine anaesthesia in lower limb surgery patients. Int $\mathrm{J}$ Basic Clin Pharmacol 2017;6:2804-10. 